\title{
Att lämna en värld \\ - om utgångsprocessen från Jehovas vittnen
}

\author{
PERNILLLA LIEDGREN DOBRONRAVOFF
}

Vad innebär det att komma till insikt om att allt det man hittills har trott varit sant är en illusion? Hur hanterar man en sådan situation och hur går man vidare? Artikeln behandlar exit-processer hos Jehovas vittnen som tvivlat på sin tro och lämnat organisationen.

\section{Inledning}

Jehovas vittnen är en religiös organisation som i vissa sammanhang definieras som en sekt. Organisationen finns över hela världen och hade i augusti 2008 7,1 miljoner medlemmar. I Sverige fanns det 2007 som mest 22739 medlemmar (Jehovah's Witnesses 2009). Jehovas vittnen grundades som organisation 1879. Kännetecknande är tron och väntan på Harmagedon då Jehova återvänder till jorden och skiljer mellan rätt-

Pernilla Liedgren Dobronravoff, socionom och fil. dr. i socialt arbete. Arbetar numera som lektor på Ersta Sköndal högskola. troende och andra. ${ }^{1}$ Tidigare utsatta datum för Harmagedon har varit 1918, 1925 och 1975. Organisationen är hierarkisk och har bestämda regler för sina medlemmar. Den som inte följer reglerna blir utesluten. Reglerna handlar om olika områden i livet - att inte ta emot blodtransfusion och att inte fira helgdagar eller födelsedagar är förmodligen kända av många. En regel som inte är så känd är den mer eller mindre uttalade regeln att inte tvivla på organisationen. Organisationen är enligt dem själva Guds organisation. Gud styr organisationen genom dess ledare. Det är naturligtvis svårt

\footnotetext{
1 Jag alternerar Gud och Jehova utom då jag skriver Jehovas vittnen.
} 
att kontrollera vad medlemmarna tänker, men det som uttalas kan kontrolleras. Det innebär att den som uttalar tvivel blir kallad till en äldstebroder i församlingen för förhör. Medlemmar som upptäcker tvivlande är ålagda att anmäla sina fränder till de äldste - annars begår de en synd mot Gud och organisationen. I samtal med de äldste bör personen ångra sina tvivel, annars blir personen utesluten. Att vara utesluten innebär att medlemmarna inom organisationen inte talar med den uteslutna. Man betraktas som en »icke-människau. Lever man i en familj där alla är med i Jehovas vittnen kan det innebära att ingen i familjen pratar med den uteslutna. För att kunna återtas i församlingen och gemenskapen ska personen gå på möten, men får då komma sist, gå först och inte prata med någon. Inte heller bör personen umgås med människor utanför organisationen - för att på så sätt visa sin hängivenhet mot Jehova och organisationen. Om tvivel på organisationen och tron uppkommer bör det alltså undertryckas eller åtminstone bör det inte visas för någon inom organisationen.

Tvivel i sig är inget ovanligt idag. Vårt samhälle uppmuntrar kritiskt tänkande där tvivlet är en av grundpelarna. Även karaktärsdragen i det senmoderna samhället gör att man utgår från tillvaron som ständigt föränderlig. En verklighet som är oförutsägbar skapar osäkerhet där tvivel på saker och tings vara är helt naturligt.

Inom Jehovas vittnen är tillvaron inte föränderlig. Åtminstone är det inte den bild organisationen och medlemmarna vill ge. Inom Jehovas vittnen får du raka, tydliga svar på existentiella frågor. Vad händer när du dör? Varför dör små barn? Är sjukdom ett straff? Hur ska man leva? Inom Jehovas vittnen följer medlemmarna de råd och regler som förordas enligt deras bibeltolkning och presenteras genom organisationens regelbundna utskick. Det är vad medlemmarna uppfattar som Sanningen om varat. Att tvivla på sanningen är helt enkelt osunt.

Den här artikeln handlar om människor inom Jehovas vittnen som tvivlat. Den handlar också om människor som efter tvivel fortsatt processen ut ur organisationen för att påbörja livet som ett ex-Jehovas vittne. Artikeln handlar om utgångsprocesser ur Jehovas vittnen.

\section{Teoretisk referensram}

I forskningen om avhopp från nya religiösa rörelser poängterar flera forskare att det är stor skillnad mellan ingångar och utgångar och även att en utgång från en rörelse inte med nödvändighet är samma som utgången från en annan (Beckford 1985, Lofland \& Skonovd 1981, Mauss 1973).

Bromley (1997) tar upp tre faktorer som har betydelse för att bedöma ingångar och utgångar som två skilda processer. För det första är ingångsprocessen ofta högt ritualiserad, något som utgången i princip aldrig är. För det andra menar han att ett engagemang $i$ själva organisationen ofta föregår det individuella engagemanget vid ingången, medan ett individuellt avståndstagande ofta föregår avståndstagandet till och utgången från organisationen beroende på att individer ofta döljer sina tvivel innan de lämnar organisationen. För det tredje konstaterar Bromley att en utgång inte nödvändigtvis avslutar relationen till den reli- 
giösa rörelsen (ibid.). Davidman och Greil (2007) har i en narrativ studie undersökt ultra-ortodoxa judars berättelser om vägen ut ur livet som ultra-ortodox. De menar att vägen ut är mycket svår eftersom det inte finns några "manus" för hur utgången skulle gå till. Resultaten är överensstämmande med Fuchs Ebaughs resultat som beskrivs nedan.

Albrecht et al. (1988) konstaterar utifrån sin forskning om individ och familjereligiöst beteende hos mormoner i USA, att det finns olika kritiska perioder i en individs liv, där han/hon har en större tendens att hoppa av. Denna period för infödda medlemmar är mellan 16 och 25 år. Vid 20-års ålder hoppar tolv av 100 medlemmar av varje år. Efter 25 års ålder sjunker nivån gradvis till ungefär en på 100 vid 40 års ålder för att därefter vara konstant. För vuxna konvertiter finns det en riskperiod de första fem åren som mormon.

I en klassisk studie om Jehovas vittnen skriver Beckford (1975) att även om avhopp sker inom Jehovas vittnen brukar inte ett vittnes karriär komma till ett snart slut. Istället är det snarare så att tvivlare förpassas/flyttar sig själva till ett medlemskap utanför gruppen av medlemmar i den centrala foran i rörelsen och blir mer och mer perifera. Eftersom vänner och familj finns kvar i organisationen menar Beckford att det för de allra flesta är svårt att helt bryta med organisationen. Trots dessa förflyttningar ut i periferin och vissa uteslutningar tenderar de före detta vittnena att inte överge organisationens värderingar och generella ideologiska dogmer (ibid.). Även Bromley (1997) påpekar att utträde ur nya religiösa rörelser inte nödvändigtvis innebär ett avslut på relationen mellan individen och rörelsen. Det är svårt att göra ett avslut på det individuella planet och därför är det ganska vanligt att före detta medlemmar organiserar sig i före-detta-medlemsgrupper för att söka stöd hos varandra.

\section{Processmodeller}

Fuchs Ebaugh (1988a) har utformat en allmän processmodell om utgången ur en roll. Hon delar in processen i fyra faser: Den första fasen börjar med att den före detta beskriver tillfället då han eller hon börjar tvivla på sina rollåtaganden. Tvivlen uppstår av olika orsaker. Det kan vara organisatoriska förändringar $i$ den sammanslutning man verkar $i$, "utbrändhetssymtom", förändringar i äktenskap eller övriga relationer som man befinner sig $i$. Dessa tvivel leder till ett motsägelsefullt beteende, cuing behaviour, som till en början är omedvetet men som indikerar missnöje med den aktuella situationen (se även Fuch Ebaugh 1988b). Den andra fasen karaktäriseras av att individen börjar söka andra alternativ. Vid detta tillfälle tenderar det motsägelsefulla beteendet att bli mer medvetet och fungerar som förstärkning av tidigare tvivel. I denna fas är omgivningens reaktioner mycket betydelsefulla. Negativa kommentarer kan komma att försena eller rent av avbryta utgångsprocessen. Tvivlaren brukar i denna situation rikta blicken mot alternativa referensgrupper och börjar i sin fantasi att pröva nya roller som ett sätt att förbereda sig för det slutliga beslutet. I det tredje stadiet, kallat turning point, vändpunkten, mobiliseras och fokuseras upp- 
märksamheten på det faktum att den gamla rollen inte längre är eftertraktansvärd. Det fjärde stadiet $\mathrm{i}$ utgångsprocessen går ut på att skapa sig en ex-roll, en före-detta-roll. Faktorer som påverkar utgångsprocessens utsträckning i tid är bland andra reversibilitet, hur definitivt beslutet är.

Fuchs Ebaugh (1988a) fann att om beslutet var definitivt så tog beslutet om utgång längre tid och individen var ofta mer medveten om konsekvenserna av sitt agerande. Beslutet var också mer centralt för individens egen identitet och brukade resultera i större upprördhet från omgivningens sida. Det gav även efterverkningar för individens hela livssituation och innebar ofta en förändring i flera andra av individens roller. De individer som $\mathrm{i}$ intervjuerna beskrivit dessa definitiva utgångar tillägnade sig snabbare en roll som en före detta. De ångrade sig också mer sällan än de som var mer tveksamma.

Fuch Ebaugh (1988a) har inspirerat flera svenska processforskare. Hedin och Månsson har beskrivit kvinnors väg ut ur prostitution (1998) och Enander (2008) har skildrat hur processerna ser ut för kvinnor som lämnar våldsamma män.

Den process Skonovd (1981, 1983) beskriver består av sju på varandra följande steg och innefattar: (1) Banden till den religiösa gruppen blir avbrutna eller neutraliserade. (2) Situationen får individen att känna spänning och/eller ifrågasätta sin religiösa tro eller åtaganden. (3) Individen börjar reagera på detta genom att reflektera över sin tro, erfarenheter och relationer för att på något sätt överkomma dissonansen. (4) Om försöken misslyckas leder det till att personen blir generellt desillusionerad.
(5) När det blir klart för personen (genom en kritisk händelse, noggrant resonerande eller någon praktisk händelse) att dessa problem inte kommer att lösas inom den befintliga religionens kontext, kommer individen att fysiskt frigöra sig från gruppen. (6) När den enskilde framgångsrikt har övervägt tankar om att återvända, floating, rädsla, skuld, meningslöshet och depression kommer denne i fas (7) att anta en identitet, livsstil och världsbild som är fri från den tidigare religiösa tillhörigheten (ibid.). Begreppet floating ser Skonovd som tiden efter avhoppet och är en slags liminalt tillstånd mellan tiden som en fullvärdig medlem i den religiösa rörelsen och tiden som en person utan påverkan av rörelsens värdesystem (ibid.). Wright (1987) använder sig av begreppet när han i sitt material om avhoppare från Enighetskyrkan, Hare Krishna och Guds barn konstaterar att ungefär 40 procent av avhopparna hade varit floaters under en tid medan elva procent av dem fortfarande var det.

Wright (1983, 1984, 1986, 1987, 1988, Wright \& Piper 1986) har studerat utgångsprocesser hos frivilliga avhoppare från Enighetskyrkan, Hare Krishna och Guds barn/ Familjen. Wright identifierar i fas ett fyra källor till desillusion, som sätter igång processen mot ett avhopp: a) ett avbrytande av medlemmarnas isolering från den omgivande världen, b) utvecklandet av ickeofficiella och oreglerade nära relationer, c) upplevelsen av utebliven framgång $i$ utvecklandet av social förändring, d) inkonsekvens i vad ledarna gör och idealen de representerar. Wrights resultat är motstridiga mot Galanter (1983) som hävdar utifrån sin studie av Enighetskyrkan att just kontrollen 
av medlemmarna var den största orsaken till avhopp (se även Lewis \& Bromley 1987). I fas två, frigörelsefasen beskriver Wright (1988) att individen söker ytterligare stimulans eller berättigande för att ge sig av från rörelsen. De berättiganden som man använder i fasen kallar Wright för underordnade faktorer och bland dessa finns ursprungsfamiljen, att återvända till skolan och undersökandet av alternativa religiösa trossystem. Wright $(1988,1987)$ menar att det inte är troligt att de underordnade faktorerna ensamma orsakar avhopp men i samband med en triggande episod (från fas ett) kan de fungera som en starkt legitimerande kraft. I fas tre väljs så strategi för avhoppet. Den slutliga fjärde fasen i frigörandet involverar en social omorientering. Familj, universitet, college, arbete eller en traditionell religiös grupp är de primära kanalerna för återvändande. Wrights forskning är svår att direkt relatera till Jehovas vittnen eftersom deras församlingar, till skillnad från de grupper Wright undersökt, har spridda åldrar. Dessutom lever inte medlemmarna inom Jehovas vittnen i kollektiv. Vidare är ofta hela familjen och ibland även släkten med i organisationen. Att då använda familjen för lösgörande $\mathrm{i}$ utgångsprocessen är inte möjligt. Ändå är den stegvisa processen intressant och har flera aspekter gemensamt med Fuchs Ebaughs (1988a) processmodell.

\section{Metoder och material}

Artikelns material består av upprepade intervjuer med tio avhoppade och tio aktiva Jehovas vittnen och informella samtal med aktiva och före detta medlemmar i Jehovas vittnen. Till grund för analysen finns också en dagbok, skriven under fyra år före uppbrottet med Jehovas vittnen. Dagboken bestod av 108 sidor maskinskriven text. Dagboken analyserades genom en emotionell innehållsanalys där texten delades in $\mathrm{i}$ olika delar utifrån författarens känslomässiga fokus. Resultaten från dagboksanalysen ställdes sedan i relation till den processmodell som utarbetats utifrån intervjuerna. De intervjuade personerna som vid intervjutillfället var aktiva Jehovas vittnen var hälften kvinnor och hälften män. Åldern var spridd mellan 20 och drygt 70 år. De intervjuades roll i församlingen och tid i organisationen varierade också stort. Den yngste medlemmen av de intervjuade i denna grupp lät döpa sig mellan de två intervjuerna och den äldste hade varit medlem i ungefär 50 år. I gruppen är fyra uppvuxna inom Jehovas vittnes familjer och sex har konverterat som vuxna. ${ }^{2} \mathrm{Av}$ de avhoppade varierade åldern mindre. Fyra av de intervjuade var mellan

2 Av gruppen fanns en man som vuxit upp med en förälder som var Jehovas vittne (föräldrarna bodde ihop). Jag placerar denne person i gruppen som "uppvuxna inom organisationen" eftersom han gick på möten, själv var aktiv och hade sin identitet där. I gruppen finns en man som under uppväxten hade en mamma som läste med Jehovas vittnen. Han själv tog del till viss del av undervisningen men lät aldrig sig döpas. Han återvände till de religiösa studierna och församlingslivet i den senare delen av 20-årsåldern varför jag placerar honom i gruppen vuxenkonvertiter. Det finns också en man som lät döpa sig tillsammans med sina föräldrar i tonåren. Honom placerar jag även i vuxenkonvertit-gruppen eftersom han hade syskon som valde att stå utanför. 
20 och 30 år och fyra kring 50 år och av de kvarvarande två var en i 40-årsåldern och den andra i 60-årsåldern. Medlemmarnas roller i organisationen representerades av vanliga församlingsmedlemmar, äldstebröder, äldstebröders fruar, biträdande tjänare (assistenter till äldstebröderna) och hjälppionjärer (en pionjär går $i$ tjänsten, dvs. missionerar minst 70 timmar i månaden, en hjälppionjär väljer att vara pionjär någon/ några månader per år). Av de avhoppade intervjuade var fyra kvinnor och sex män. Av de avhoppade Jehovas vittnen som intervjuades var sex uppvuxna inom organisationen. De avhoppade vittnena hade under medlemskapet haft olika roller, pionjärer, hjälppionjärer, äldstebröder, assistenter. En tidigare betelit från det svenska Betel (områdeskontoret i Sverige) fanns även representerad. ${ }^{3}$ Access till aktiva Jehovas vittnen fick jag genom att kontakta en församling inom Jehovas vittnen. Min önskan om intervjuer diskuterades mellan några äldstebröder och därefter gick de med på att förmedla kontakt till tio medlemmar som jag skulle få intervjua. Naturligtvis går det att kommentera att äldstebröderna säkerligen valde ut personer de ansåg skulle representera organisationen väl i en akademisk studie. Men att få tag på andra Jehovas vittnen för att genomföra intervjuer skulle vara omöjligt eftersom alla beslut om medverkan i aktiviteter utanför organisationens egen regi går genom församlingens eller organi-

3 "Betel" heter organisationens kontor, oavsett om det är huvudkontoret i Brooklyn, New York eller områdeskontoret i Arboga, Sverige. En betelit är en person som arbetar på ett Jehovas vittneskontor, ett Betel. sationens ledare. Genom att ställa de aktiva vittnenas berättelser mot de före detta vittnenas berättelser var min förhoppning att eventuella svart- eller vitmålningar skulle kunna balanseras. De före detta medlemmarna fick jag tag på via avhopparorganisationer, via snöbollsmetoden och via vänners avlägsna kontakter. Intervjuerna och dagboken var en del av empirin som användes i avhandlingen Att bli, att vara och att ha varit - om ingångar i och utgångar ur Jehovas vittnen (Liedgren Dobronravoff 2007).

Var intervju tog mellan en timme och två och en halv timme. Det gjordes två intervjuer med varje intervjuperson. Intervjuerna bandades och skrevs ut ordagrant. Vidare har de analyserats genom att återkommande teman uppmärksammats och koncentrerats. Empirin består till största delen av berättelser. Berättelser är alltid konstruktioner. Personerna som intervjuats väljer att $\mathrm{i}$ intervjun ge en berättelse med vissa karaktäristika, de väljer att framhäva vissa saker på bekostnad av andra allt utifrån den intervjuades eget behov (Gabriel 1991). Vad intervjupersonerna framhäver beror på hur de vid tillfället erfar minnet vilket är format av upplevelser, bearbetningar, minnets svaghet och mycket annat. Jag har försökt att blanda urvalet utifrån ålder, kön, position i organisationen, utbildning men även, som jag tidigare nämnt genom att jämföra mellan avhoppare och aktiva Jehovas vittnen. I den här artikeln kommer material och slutsatser från främst avhopparna att framträda, även om det $\mathrm{i}$ den analytiska processen har ställts mot berättelserna av de aktiva Jehovas vittnen. Hydén (1997) menar att en berättelse alltid pressar undan en annan berättelse och

Pernilla Liedgren Dobronravoff: Att lämna en värld... 
genom att även intervjua aktiva Jehovas vittnen möjliggörs en nyansering av berättelserna. I den följande presentationen återges Jehovas vittnen med namn som börjar på A och de före detta Jehovas vittnen presenteras med namn som börjar på F. Dagboksförfattaren återges som Håkan.

\section{Kontextuell förståelse}

De krafter som är i vardande för en person som funderar på att lämna Jehovas vittnen har jag benämnt uppbindning och avskärmning. Det är faktorer som har påverkan på medlemmar. Vid höga värden gör de utgångsprocessen svårare. För att få en förståelse av utgångsprocessens krafter och betydelser är det viktigt att ha kunskap om dessa faktorer.

\begin{tabular}{|c|c|}
\hline Uppbindning & Avskärmning \\
\hline Närhet och vänskap & Arbetssituationen \\
\hline Bekräftelse & 'Stängda dörrar' \\
\hline
\end{tabular}

\section{Uppbindning/avskärmning}

Väl som medlem i Jehovas vittnen finns det faktorer som medverkar till att intervjupersonerna blir allt mer uppbundna av organisationen. En uppbindande faktor är något som knyter personen närmare till organisationen. Den första av de uppbindande faktorerna är Närhet och vänskap. Här åsyftas den gemenskap och känslomässiga bindningar som uppstår mellan medlemmarna. Begreppet Bekräftelse handlar om de möjligheter som finns till att bli sedd inom församlingen för de insatser intervjupersonerna gör för sin tro. Dessa två faktorer bidrar till att binda upp dem till organisationen.

En avskärmande faktor avskärmar medlemmen från det omgivande samhället. Arbetssituationen syftar till att beskriva hur arbetsplatser med många vittnen och även koncentrationen av Jehovas vittnen i vissa yrkesgrupper har funktionen till att avskilja individen från omvärlden. 'Stängda dörrar' står för de stängda möjligheter som organisationen indirekt bidrar till genom de råd och normer som presenteras för medlemmarna. Både uppbindning och avskärmning har funktionen för individen att denne betraktar livet $\mathrm{i}$ organisationen som alltmer oumbärligt. Nedan kommer jag mer utförligt att beskriva faktorerna.

\section{Närhet och vänskap}

Albert berättar om närheten till församlingsmedlemmarna som han känner: Man fär ju ett annat förhaillande till.... som vi kallar det, bröder och systrar. Man blir...//... andliga syskon och ... blir väldigt nära varandra .... Öppenhjärtig, man delar de stora målen i livet. Albert tar upp den närhet mellan medlemmarna som är ett resultat av att de bekänt sig till samma tro.

Närheten till varandra gör ofta att medlemmarna har svårt med umgänge med personer där det saknas närhet och en gemensam värdegrund. August förklarar varför han hellre umgås med personer som delar hans tro istället för studenterna vid universitetet där han studerar: Konflikterna blir så stora när det gäller vissa områden ... De pratar [i klassen] hela tiden om sina fester som jag inte deltar $i$...//...Jag har inget att 
tillföra diskussionen och jag fär ingenting ut av den. Det är lätt att förstå att August får mer utbyte av umgänge inom Jehovas vittnen än med människor som inte delar tron eftersom normer och värderingar bryter av mot det omgivande samhället.

För de allra flesta, uppväxta och döpta som vuxna, är den sociala och andliga gemenskapen en stark orsak till att stanna kvar i organisationen. Att en utgång ur organisationen omfattar en förlust av närhet och vänskap bekräftas av flera av avhopparna. Samtidigt som en uteslutning medför en förlust av vännerna i organisationen innebär ett medlemskap ett avbrytande av många av de vänrelationer som det blivande vittnet har utanför organisationen. Ameli, som under tiden mellan intervjuerna döper sig, berättar att hon inte umgås mycket med sina gamla vänner: Helt plötsligt har man ingenting gemensamt längre. Innan, ../l..pratade vi sex och pojkar, mode och kläder.../. Vilket nu känns väldigt tomt.

Den närhet och vänskap som finns mellan medlemmarna i organisationen är något de får klara sig utan vid en eventuell utgång, det är något som görs klart för medlemmarna vid inträdet. Trots denna vetskap kan det vara svårt för medlemmen att överblicka konsekvenserna och för en del blir det verklighet först när de befinner sig i situationen. Felicia berättar om vad som skedde efter hennes utträde: ...//... alla nära och kära inom Jehovas vittnen miste jag i ett slag. Det var lika bra att jag flyttade frän orten ..../... för det var hemskt, att möta dem på gatan och de tittade ner $i$ marken. Att inte längre bli sedd av personer som hon tidigare betraktat som närstående upplevde Felicia som svårt. Frank berättar om hur han funderade inför avhoppet: .... jag kände att om jag inte tycker detta till 100 procent, då ska jag inte vara med...//... Men jag ville ändå inte lämna, för det skulle bli så jobbigt med släkt och kompisar och sånt för de skulle inte kunna ha nagon kontakt med mig. Frank hade, på grund av relationerna, svårigheter att lämna organisationen, trots att han inte hade tron längre. Fredrika anser att livet i organisationen var bra för familjen och att hon upplevde det sociala livet i församlingen som positivt: Ja, jag saknar mina vänner naturligtvis, och min syster ....//... Vi hade det bra när vi var där, jag längtade aldrig därifrån. Ungarna hade en jättebra uppväxt och vi hade många vänner och så.

Håkans stora problem när han skulle gå ut ur organisationen var att hans fru och barn var medlemmar och att han inte ville lämna rörelsen utan dem. Av de avhoppade vittnena har tre haft döpta barn i organisationen. I samtliga fall har barnen också gått ut ur organisationen vid ungefär samma tidpunkt som föräldrarna. Att ingen av avhopparna haft barn som fortsatt att vara medlemmar i organisationen när föräldrarna gått ut indikerar att det möjligtvis finns fler medlemmar som Håkan i organisationen, som bidar sin tid tills tillfälle ges då hela familjen kan gå ut. Detta eftersom det skulle innebära en alldeles för stor känslomässig kostnad att lämna familjen och inte kunna ha kontakt med dem. Det är också troligt att chansen aldrig kommer för en del tvivlande medlemmar som då får leva resten av sina liv med en livslögn eftersom ett avhopp/uteslutning skulle innebära alltför kostsamma konsekvenser för dem.

Felix som är uppvuxen i en Jehovas vittnesfamilj berättar om sitt krympta nätverk 
efter utgången. Från att ha varit en person med många släktingar stod han plötsligt ensam:

Det som var jobbigt var väl ... // ... jag hade en extremt stor släkt. Den uppgår nog till en 80 personer med kusiner och morbröder och... och alla är med [i Jehovas vittnen] utom en kusin som är utesluten. Men han vill inte ha nått med mig att göra för han anser fortfarande att det är sanningen.

På grund av att Felix tagit avstånd från tron och begärt utträde ur organisationen vill ingen av hans släktingar ha någon kontakt med honom.

\section{Bekräftelse}

I organisationen finns möjligheter till status och erkännande för medlemmarna, enligt intervjuerna. Mest valmöjligheter står till förfogande för männen som kan bli äldste, biträdande tjänare, pionjär och betelit. Kvinnor kan bli pionjärer. De kan också bli beteliter, men bara om de är gifta och maken också är betelit. Kvinnor får även erkännande genom att deras make har en position och att de är stödjande fruar. Felix berättar:

... Det går inte att komma ifrån. Är du biträdande eller äldste eller pionjär, då har du bättre status. Då fär man börja hälla tal... I/... folk ser upp till en på ett annat sätt. Så det var en liten kick ... //... // De flesta kvinnor, det är ju de som utför det mesta arbetet med att gå i tjänsten. Som min fru som blev pionjär till exempel. Det är ju också lite status, då kan man efter ett år gå pionjär- skola... sen är det många kvinnor som gör en slags karriär som duktiga äldstefruar. Det är ju lite finare då. Att ens man är äldste, och att man stöttar honom och ställer upp för honom och så ... //... Min frus kompis gifte sig med en på Betel i Arboga.... Då fick hon komma dit. Det var också lite fint.

Inom organisationen finns möjligheter till bekräftelse genom att ägna tid åt församlingen eller försöka värva nya medlemmar. Denna bekräftelse från andra medlemmar menar Håkan är förförisk. Håkan skriver i sin dagbok: Var $i$ X-stad och höll föredrag. Den konstiga känslan av välbehag infann sig och det jag tänker göra var så fjärran. Håkan menar att de känslor av välbehag som rollen som äldste ger honom strider mot det han egentligen vill, bort från organisationen. Filip berättar om den möjliga karriären i Jehovas vittnen: En del väljer ju att göra det som en karriär, de känner att de blir någonting när de kan arbeta upp sig i organisationen. De har oftast satsat hela sitt liv.

\section{Arbetssituationen}

De råd organisationen ger sina medlemmar gällande yrkesval är att arbeten utan för mycket engagemang och utbildning, som ger dem möjlighet att lägga tid och energin på tron är att föredra (Jehovah's Witnesses 1999, 1998, 1982). Det har lett till att många vittnen arbetar med enkla manuella arbeten. Av de aktiva vittnen jag intervjuat studerar två på högskolan och en har högskoleutbildning. Av de kvarvarande sju arbetar eller arbetade (några är nu pensionärer) alla med arbeten som inte kräver 
någon längre utbildning och bara en har ett arbete som kräver kontinuerlig och nära kontakt med människor. Bland de före detta vittnena som jag intervjuat har alla utom en vid tiden för sitt medlemskap haft arbeten som inte krävt någon längre utbildning eller förutsatt kontinuerlig och nära kontakt med andra. Felix var av de före detta vittnena ensam om att under den sista tiden som medlem arbeta på en arbetsplats dominerad av Jehovas vittnen. Av de intervjuade aktiva vittnena arbetar Alfred, Adam och Alexander på arbetsplatser där det finns många kolleger som är vittnen. Alfred arbetar på en liten firma där hälften av personalen är Jehovas vittnen. Alexander arbetar på en arbetsplats där företaget ägs av ett Jehovas vittne och där majoriteten av personalen är vittnen. Genom att vara flera vittnen på samma arbetsplats kan medlemmarna vara ett stöd för varandra.

"Stödet" i arbetssituationen får även andra konsekvenser. Om man börjar tvivla på tron kan stödet upplevas som kontroll. Felix ger sin förklaring till varför han blev sjukskriven:

Utmattningsdepression.... det var väl egentligen inte för att jag hade jobbat mycket utan mer psykiskt. Jag hade börjat ... //... ifrågasätta mycket. Och sen jobbade jag bara med vittnen, och kunde inte prata med någon av dem. De undrade varför jag inte gick $p a$ mötet ... tog jag upp en diskussion så gick de till äldstebröderna och telefonen ringde i ett. Jag fick magsår.

Genom att varken på fritiden, på arbetet eller hemma kunna tala fritt om sina tvivel och om vad han kände utvecklade Felix till sist både magsår och mutmattningssymtom». När han senare tog steget och begärde utträde innebar det problem på andra områden: Det har ju blivit jobbigt naturligtvis. Dels med att jag förlorade mitt jobb. Jag hade också ett eget kontrakt hos en firma, som jag förlorade på grund av att den jag hade kontraktet för också var vittne. Eftersom Jehovas vittnen inte får prata med uteslutna går det inte att arbeta ihop. Men det finns vinster med det nätverk av ideologiskt likriktade medlemmar organisationen erbjuder. Adam har ett eget företag där han av 14 anställda hade tre vittnen anställda. Adam berättar: Jag har varit egen företagare i 25 àr och har märkt att ... det är bäst att anställa Jehovas vittnen, för de verkar vara ärligast. Vi har haft störst problem med dem som... // ... som varit utanför vår organisation. Även om Adam inte kräver att de som arbetar för honom är vittnen säger han att han föredrar anställda som är av samma tro. När Alfred flyttade till $\mathrm{X}$-stad hade han inga svårigheter att få jobb i en städfirma ägd av ett vittne i den nya grannförsamlingen. Det finns i organisationen ett nätverk av arbetsgivare och arbetstagare i städ- och fönsterputsbranschen som gör att medlemmar i en vänskaplig anda lätt kan skaffa sig ett arbete eller söka anställda till sina företag.

\section{'Stängda dörrar'}

Alfred svarar följande på frågan om han ångrar att han inte fortsatte sin utbildning efter högstadiet:

Nej, det gör jagfaktiskt inte. För att jag tycker att ... dels så har jag haft så bra jobb hela 
tiden ... //... jag har haft en sain himla frihet. Jag har insett det för ganska länge sedan att den friheten jag har, den är värd mycket, pà många sätt. Jag har fortfarande väldigt bra villkor, även om jag på pappret jobbar heltid så kan jag vara ledig varje onsdag. Jag kan sluta tidigare många dagar, speciellt nu pa sommaren. Jag gör klart mitt jobb och sen går jag hem och tar med mig frugan och åker till stranden. Dåkänns det bättre.

Alfred framställer sin brist på utbildning som något positivt, något som resulterat $i$ att han har haft en stor frihet genom de enkla arbeten som han har haft. Han säger att när han slutat sitt "jobb" för dagen åker han hem och hämtar sin fru och de åker till stranden, men tillägger: Då känns det bättre. Jag tolkar hans berättelse som att han inte är helt nöjd med sin arbetssituation, men att livet utanför arbetet ger honom tillfredställelse som väger upp de försakanden han måste göra. Detta är tydligen ändå inte tillräckligt. Mellan intervju ett och två byter Alfred arbete till ett förmodligen mer välbetalt jobb som försäljare. Att byta yrke från städare till försäljare gör han vid 26-års ålder utan någon större svårighet. Men hans bristande utbildning ger honom ingen större valfrihet vid framtida yrkesbyten. Filip berättar om de förlorade chanserna i samhället utanför Jehovas vittnen vid ett längre medlemskap:

Att lämna Jehovas vittnen betyder att de inte har någon vettig position $i$ samhället. Ofta har de väldigt enkla jobb. Det kan vara brevbärare, att städa, det är väldigt vanligt - lokalvaird i olika former. De har små firmor de håller på med. Men det är ju ingenting som kan bli någon framtid egentligen.

Genom att inte utbilda sig, göra karriär eller engagera sig i det omgivande samhället kommer många medlemmar att så småningom bli alltmer hänvisade till organisationen. Det gör att ett återvändande till ett liv med karriär, status och en god lön i samhället utanför Jehovas vittnen blir allt svårare, ju längre personen stannar. Frida som var 35 år när hon fjärmade sig från organisationen, började studera på den kommunala vuxenutbildningen eftersom hon inte hade några gymnasiebetyg. Fyra av avhopparna saknade gymnasiekompetens. Anledningen som de intervjuade angav var Jehovas vittnens negativa attityd gentemot världslig utbildning som gjort att de valt bort att läsa vidare.

\section{Utgångsprocessen}

Som en del i analysen har en utgångsmodell utarbetats där olika faser manifesterats som ungefärliga perioder personerna går igenom när de lämnar rörelsen. Processmodellen såsom jag tecknat den nedan är inte med nödvändighet kronologisk. Tiden en individ behöver i de olika faserna varierar stort. Av materialet utläses att det för medlemmarna är nödvändigt att bearbeta varje fas för att i slutändan inte kvarstå i Jehovas vittnens tankeuniversum. Utgångsprocessen ter sig, till skillnad mot ingångsprocessen som mindre tydlig i strukturen vilket kan bero på det stöd man har av församlingsmedlemmar vid en ingång (Bromely 1997, Davidman \& Greil 2007, Fuch Ebaugh 1988a, Liedgren Dobronravoff 2007). 
De faser i utgångsprocessen som jag har kunnat identifiera är följande: olika grader av tvivel, prövning av tvivel, vändpunkter, olika beslut, olika steg i verkställigheten, floating och relativ neutralitet. Nedan en idealtypisk modell av utgångsprocessen:

\begin{tabular}{|c|c|}
\hline Faser & Kommentar \\
\hline $\begin{array}{l}\text { 1. Olika grader } \\
\text { av tvivel }\end{array}$ & $\begin{array}{l}\text { Olika grader av tvivel } \\
\text { förekommer under hela } \\
\text { utträdesprocessen }\end{array}$ \\
\hline $\begin{array}{l}\text { 2. Prövning av } \\
\text { tvivel }\end{array}$ & $\begin{array}{l}\text { Intervjupersonerna gör } \\
\text { någon form av prövning } \\
\text { av tvivel. }\end{array}$ \\
\hline 3. Vändpunkter & $\begin{array}{l}\text { I forskningen brukar } \\
\text { man tala om olika typer } \\
\text { av vändpunkter i en } \\
\text { utträdesprocess. Vissa } \\
\text { vändpunkter har större } \\
\text { betydelse än andra, och } \\
\text { blir avgörande för om } \\
\text { medlemmen ska stanna } \\
\text { kvar i organisationen } \\
\text { eller inte. }\end{array}$ \\
\hline 4. Olika beslut & $\begin{array}{l}\text { Olika beslut tas under } \\
\text { utträdesprocessen. } \\
\text { Vissa är mer avgörande } \\
\text { än andra. }\end{array}$ \\
\hline $\begin{array}{l}\text { 5. Olika steg i } \\
\text { verkställigheten }\end{array}$ & $\begin{array}{l}\text { Besluten kan verkställas } \\
\text { på olika sätt och i olika } \\
\text { steg. }\end{array}$ \\
\hline 6. Floating & $\begin{array}{l}\text { Tankar som medlem- } \\
\text { marna har kring rädsla, } \\
\text { skuld, meningslöshet } \\
\text { och tankar om organisa- } \\
\text { tionens påverkan i olika } \\
\text { stadier av utträdespro- } \\
\text { cessen. }\end{array}$ \\
\hline $\begin{array}{l}\text { 7. Relativ neutra- } \\
\text { litet }\end{array}$ & $\begin{array}{l}\text { Intervjupersoner har } \\
\text { kommit över sina käns- } \\
\text { lor gentemot organisa- } \\
\text { tionen och en relativ } \\
\text { neutralitet inträder. }\end{array}$ \\
\hline
\end{tabular}

\section{Olika grader avtvivel}

Det som utlöste utgångsprocessen hos mina informanter var att de upptäckte brister i ideologi, att de hade arbetat mycket och var uttröttade, att de upplevt för högt ställda krav från organisationen eller reagerade på beteendet hos de andra medlemmarna i organisationen. Följderna i samtliga fall blev att medlemmarna började känna tvivel. Vissa tvivel är starkare än andra. Intervjuerna indikerar att de som har växt upp inom organisationen hade lättare att börja tvivla, förmodligen eftersom de själva i grunden inte tagit ställning för tron när de lät döpa sig. Det kan också vara så att de åldrar i en människas liv när ifrågasättande är mer vanligt (ungdomsåren) även får genomslag i utgångar hos Jehovas vittnen. Albrechts et al. (1988) forskningsresultat stödjer den tolkningen. Tvivlet, som föregår det slutgiltiga beslutet har enligt de intervjuade infunnit sig mellan ett och sex år innan själva avhoppet. Men det finns också exempel där tvivlen uppkommit veckor före beslutet - i Felicias fall åtta veckor. I "Håkans» fall uppkom tvivel 19 år före beslutet.

Filip berättar att hans första tvivel infann sig när han arbetade på Betel. Eftersom han alltid varit historieintresserad läste han mycket av organisationens äldre litteratur som fanns i biblioteket på Betel. Han berättar:

Jag började läsa mycket av den gamla litteraturen, som alltså är från seklets början.. /... Det gjorde att jag började fundera. - Det stämmer inte riktigt här! De har ändrat så oerhört mycket. Jag följde frågor, kunde 
följa deras gamla årgångar... //. och såg hur mycket som ändrats. Så jag började ifrågasätta. Mer och mer ställde jag frägor... //... jag började samtala med några vänner inom organisationen, vittnen ... // ... Vi blev som en liten grupp som började sitta och resonera. ... //... till en början fick jag hälla det hemligt för min dåvarande fru.

För Filip skapar de förändrade bibeltolkningarna över tid, i kombination med att organisationen alltid hävdat att de har sanningen, förvirring och tvivel: Hur kan sanningen förändras så ofta? Flera före detta vittnen berättar om deras upptäckt av inkonsekvenser mellan organisationens sätt att använda bibelcitat som de upptäckt genom studier av Bibeln på egen hand. I en kontext där riktlinjer för hur man ska leva och tydliga rätt och fel regelbundet instrueras genom organisationens skrifter blir sådana inkonsekvenser mer betydelsefulla än det skulle vara för en individ i det omgivande samhället. Att man sen inte får diskutera inkongruenserna i bibeltolkningar är i och för sig konsekvent i organisationens grundsyn där de har patent på sanningen. Samtidigt gör förbudet att diskutera inte att tvivlen upphör. Frej, Fanny och Frida bekräftar förutom Filip att deras tvivel handlat om dessa frågor. Om en medlem uttrycker tvivel ska denne anmälas till de äldste och ett kommittéförhör följer där medlemmen måste erkänna att de har gjort fel på grund av svaghet $\mathrm{i}$ tron. För att slippa att bli anmälda kunde Filip och Håkan inte diskutera sina tvivel med sina fruar.

Fredrika kände tvivel när hon hörde de äldste predika om ödmjukhet, samtidigt som de kunde utesluta 15-16 åriga barn med oönskat beteende istället för att hjälpa dem. Hon kunde inte förstå att uteslutning av barn skulle vara kärleksfullt. Fredrikas funderingar och tvivel kan relateras till Wrights fjärde punkt av skäl till tvivel: en slags upplevelse av inkonsekvens i vad ledarna gör och idealen de representerar (Wright 1983, 1984, 1986, 1987, 1988, Wright \& Piper 1986). Frank berättar att han träffade en flicka när han gick i gymnasiet som blev hans första kärlek. Hon var inte ett vittne och hade heller inga önskningar om att bli det. Den unga kärleken uppmärksammades av äldstebröderna som tvingade honom att göra slut med flickan med motivet att hon kunde vara skadlig för honom. Besvikelsen och den olyckliga kärleken initierade Franks tvivel.

Fred kom allt mer att dra sig undan från organisationen när han förstod att han inte kunde kontrollera sig enligt de beteenderegler som organisationen hade fastställt. I det här fallet handlade det om otillåten masturbation. Han tog upp ämnet med äldstebröderna några gånger. Rådet han fick var att härda ut, vilket inte hjälpte när lusten vaknade. Egentligen ifrågasatte han inte organisationens regelverk utan bara sin egen förmåga till kontroll. Tvivlet riktades mot den egna personen. När han vid ett tillfälle flyttade tog han inte kontakt med den nya församlingen eftersom han kände sig ofullkomlig. Först många år efter fjärmandet från organisationen och efter att på olika, icke framgångsrika sätt, försökt att undertrycka tankar om sin oförmåga till kontroll började Fred att gå i psykoterapi. Han berättar att han då fick klart för sig vilken roll kraven inom organisationen har spelat för hans liv. Flera av avhopparna 
tror att antalet avhoppade/uteslutna på grund av oförmåga att kontrollera sitt beteende är större än det antal som lämnar rörelsen av andra orsaker.

Frida berättar att hon tog ett initiativ att samlas för en pic-nic fest på midsommarafton. Initiativ till stora fester ska förankras hos äldstebröderna, det har flera intervjupersoner berättat. Resultatet av festinitiativet blev att äldstebröderna krävde att Frida ställde in festen, vilket, hon uppger ökade besvikelsen och tvivlet hos henne. Samtidigt går det inte att undgå att konstatera att Frida på ett, förmodligen omedvetet sätt sökte provokationen. Hon visste säkert att festinitiativ skulle förankras, att sedan välja midsommarafton som festdag i en organisation som avsäger sig allmänna festligheter gör att det kan gå att tolka Fridas handlande som ett cuing behaviour (motsägelsefullt beteende). Fuch Ebaugh (1988a) pratar om cuing behaviour som beteenden som indikerar individens tvivel, även om det fortfarande är omedvetet.

Felicia och Frida beskriver att de gjorde allt för att vara organisationen till lags genom att gå många timmar $i$ tjänsten samtidigt som Felicia arbetade heltid och Frida både förvärvsarbetade och tog hand om sin familj. De upplevde att det aldrig var tillräckligt, utan de förväntades hela tiden göra mer. Både Felicia och Frida menar att de i efterhand har insett att de var utarbetade och att tvivlet till viss del grundats på att de var så slitna. Fuchs Ebaugh (1988a, 1988b) lyfter, i sin forskning om nunnor som lämnar sina katolska ordnar, fram tvivel som initierats av "utbrändhet" och känslan av att inte räcka till. Denna form av hård kontroll och höga krav på medlemmarna gjorde inte att organisationen kunde förhindra avhopp. Kontroll och krav motverkade inte avhopp för Fuchs Ebaughs nunnor, inte heller för Felicia och Frida. Samtidigt finns det exempel på motsatt effekt i de utrensningsaktioner som företagits från Jehovas vittnens sida. När många kritiska tvivlare funnits i organisationen har många av dessa blivit uteslutna, normerna för beteendet har stramats upp och därefter har kritiken tystnat. Dogmer som reglerar beteenden är å ena sidan viktiga orsaker till avhopp enligt Galanter (1983) som studerat Enighetskyrkan. Wright (1987) å andra sidan drar slutsatsen utifrån sin forskning av Guds Barn, Hare Krishna och Enighetskyrkan, att för lite kontroll av individen startar avhopparprocesser. Kanske går det att förstå ovanstående som att det i första fallet (Felicia och Frida) var själva "utbrändheten" som orsakades av krav från organisationen som initierade tvivel och utgångsprocess och som i ett senare skede ledde till avhopp. ${ }^{4}$ I det andra fallet agerar organisationen auktoritärt och lyfter bort oönskade element vilket ger gruppsykologiska efterverkningar hos de kvarvarande som gynnar följsamhet till organisationen. I det första fallet har individerna tillåtits att vara och verka i tvivel och utgångsprocess. I det andra föregår organisationen kritikerna och överraskar medlemmar som kanske inte är fullt mogna att ta steget ut ur organisationen just nu vilka då förmodligen skräms till tystnad.

4 För de symptom utmattningssyndrom kan ge, se Socialstyrelsen (2003). 


\section{Prövning av tvivel}

Att gå från tvivel till insikt innebär en oerhörd osäkerhet eftersom marken under de intervjuades fötter skulle försvinna om tron inte skulle vara sann. Men tvivlen måste ändå prövas på något sätt. I Fuchs Ebaughs andra fas börjar individen att söka andra alternativ. Hon menar att det tidigare motsägelsefulla omedvetna beteendet, som var betecknande för steg ett, blir allt mer medvetet. Omgivningens beteende är, här mycket betydelsefullt, de presumtiva avhopparna riktar blicken mot alternativa referensgrupper (1988a). Håkan berättar i sin dagbok att han söker sig till körverksamhet utanför organisationen. Frida började studera och arbeta som lärare och Fredrika började även hon att sjunga i kör. Hälften av de före detta vittnena läste också avfällingslitteratur (kritisk litteratur om organisationen skriven av före detta vittnen) under tvivelstiden.

Ett annat sätt att pröva tvivel har varit att samtala. Åtta av de avhoppade vittnena hade möjlighet att diskutera tvivlen med någon annan som var insatt i organisationen. Fred och Felicia hade inte någon att diskutera sina tvivel med och tycks ha haft en svårare tid efter avhoppet. Orsaken kan vara att de inte kunde ventilera sina tankar med någon utomstående. Felicia, lämnade första gången organisationen snabbt, innan hon hunnit grundligt ompröva organisationens fundament. Efter avhoppet väntade hon sig att Harmagedon skulle komma endera dagen. Förutom denna överhängande dom pratade inte hennes familj eller gamla vänner med henne. Möjligtvis går det att se utanförskapet som orsak eller delor- sak till att hon utvecklade depression och anorexia.

\section{Vändpunkter}

Insikten om att organisationens ideologi inte är rätt utgör det femte steget i Skonovds modell (1981). Insikten växer fram, enligt Skonovd, genom noggrant resonerande och en kritisk eller en praktisk händelse. Fuchs Ebaughs (1988a) tredje stadium benämns Vändpunkten och fokuserar på det faktum att den gamla rollen inte längre är eftertraktansvärd. Jag menar, till skillnad från Fuchs Ebaugh och Skonovd att vändpunkter också kan vara resultatet av en serie händelser. Jag menar även, med stöd av min empiri, att vändpunkterna kan vara flera. Vad som inträffar i denna fas är att personen inte kan förlika sig med den världsuppfattning som han eller hon haft. En slutlig vändpunkt infinner sig när en person intellektuellt och känslomässigt omprövar det val som denne tidigare har gjort. Håkan upplever under sin utgångsprocess flera vändpunkter, till exempel när han börjar skriva dagbok första gången eller när han börjar skriva dagbok för andra gången. Det går att i efterhand konstatera att vissa vändpunkter har haft större betydelse än andra. Att återigen börja skriva dagbok var ett betydelsefullt steg, eftersom Håkan redan varit med om dagboksskrivandet, dess avslöjande och beslutet att lämna och sedan beslutet att stanna kvar i organisationen. Han berättar i efterhand att han visste, när han började med skrivandet igen, att det inte längre fanns någon återvändo. På något sätt måste han denna gång 
definitivt lämna organisationen. I intervjuerna pekas sällan någon speciell tidpunkt eller tillfälle ut som vändpunkt. Fanny, som är ett av undantagen berättar:

Det var det värsta när man kom på att det här inte kan stämma - jag har inget liv utanför det här. Jag har ingenting. Jag har inga kompisar, jag har inget framtidshopp, jag har ingen, nej, ingenting. Allting somjag har haft innan är helt borta. Det var så jag tänkte. Det finns inget mer. Man kan lika gärna lägga sig ned och dö.

Insikten om att den världsbild som man har haft som sitt rättesnöre under hela livet är falsk, är för den enskilde en traumatisk upplevelse. Även Frej uppger att hans verklighet rasade samman när han insåg att det han trott på i hela sitt liv inte var sant. Men han uppger inte något datum eller någon händelse i anknytning till detta. För övriga informanter verkar vändpunkterna vara flera kritiska händelser, insikter och tvivlande tankar i samspel med en församling där tvivel betraktas "som suspekt» och där kontakten med kritiker undviks i det sociala livet.

\section{Olika beslut}

Beslut tas vid flera tillfällen under utträdesprocessen och kan vara mer eller mindre medvetna och beröra saker av olika dignitet. Likväl som beslutet kan handla om den slutliga utgången kan beslutet röra små ting som när Håkan bestämmer sig för att vara uppmärksam på hur familjemedlemmarna förhåller sig gentemot organisa- tionen. Beslutet kan också handla om att bestämma sig för att servera en lögn för att snabbt bli utesluten som i Felicias fall. Felicia ljög när hon berättade för äldstebröderna att hon haft sexuellt umgänge med en pojke utanför församlingen vilket resulterade i att hon blev utesluten (vilket var hennes önskan att bli).

Beslutet att gå ur organisationen verkställs inte alltid direkt på grund av de sociala kostnaderna det innebär. Håkans beslut att gå ut ur organisationen togs vid flera tillfällen utan att han verkställde dem. Beslut tog han tillsammans med sin fru den gången, för flera år sedan, då han hade visat henne dagboken. Beslut togs även inför Turkietresan och slutligen när sonen kommer till honom och berättar om sina tvivel och att han inte längre vill vara kvar i rörelsen. Felix berättar vad som låg till grund för beslutet att begära utträde. Insikten som föregår beslutet kan betraktas som en vändpunkt:

... // jag började fundera så här: - Om jag går med $i$ ett nazistparti, och stöder deras ideologi. Och sen helt plötsligt fär jag för mig: 'Men, utländska människor är minst lika mycket värda som vi svenskar är.' Men är ändå kvar i partiet. Då innebär det att jag stödjer de åsikterna, så länge jag inte öppet säger att jag inte vill ha med dem att göra. Så började jag känna med Jehovas vittnen också.

Beslutet att gå ur organisationen blev till slut oundvikligt. När Felix försökte diskutera sina tvivel med vänner i församlingen blev han ifrågasatt på grund av bristande solidaritet. Det fanns inget utrymme för 
diskussion. Fördelarna med att vara kvar i organisationen gick inte att motivera med den höga moraliska kostnad som det medförde att hela tiden förneka sin egen övertygelse.

\section{Olika steg i verkställigheten}

Förutom att som Felix och Felicia gå ut ur organisationen strax efter beslutet finns exempel på medlemmar som trots ett beslut att gå ut ur organisationen stannar kvar, då de vill hjälpa andra medlemmar som står i begrepp att lämna organisationen. Filip berättar att han tillsammans med andra medlemmar som ifrågasatte Jehovas vittnens undervisning samlades i en grupp. I gruppen studerades Bibeln på egen hand för att undersöka i vilken relation Jehovas vittnens undervisning stod till bibeltexterna. Detsamma gjorde även Fredrika, Fanny och Frej. Frej och Fanny berättar att de studerade Bibeln vid sidan om organisationens aktiviteter och diskuterade med andra tvivlare, innan de slutligen blev uteslutna. Av de intervjuade är det bara två som har skrivit ut sig själva ur organisationen. Trots det har ingen av informanterna blivit uteslutna ofrivilligt.

Skälen till varför man dröjer med att gå ut ur organisationen kan vara att man vill ha med sig sina familjemedlemmar, eller att man vill hjälpa vänner som har svårt att ta beslutet att gå ut ur organisationen. Avhopparna menar att det finns många individer inom organisationen som inte tror på läran och som skulle vilja hoppa av, men att de inte vågar eller tycker att de kan på grund av familjeskäl. En annan anledning att en utgång ur en ny religiös rörelse tar lång tid är osäkerheten och ovissheten om vad som komma skall. Att gå från en mycket förutsägbar tillvaro till något ovisst ökar oron, vilket även har visats av Bromley (1997).

\section{Floating-bearbetning}

Begreppet floating har tidigare beskrivits under teoriavsnittet som fasen i utgångsprocessen då personen funderar på att återvända, känner skuld, rädsla, meningslöshet och depression (Skonovd 1981, Wright 1987). I min tolkning av begreppet innefattas individens reflektioner om hur medlemskapet påverkat dem som även innefattar känslor av hämnd, hat och bitterhet. Det innebär för mina informanter bearbetning av och reflektioner om relationerna till organisationen. Tiden för bearbetning har för de intervjuade varit olika dramatisk. Felicia, som blivit utesluten två gånger, tänkte inte - vid den första uteslutningen - riktigt igenom sitt beslut. Det innebar att hon fastnade i floating-fasen. Istället för att gå vidare mot relativ neutralitet var hon fast i organisationens ideologiska universum. Oroligt väntade hon på jordens undergång då hon skulle gå mot en säker och smärtsam död. När hon återvände till organisationen kunde hon återuppta sin utgångsprocess och gick sedan ut ur organisationen efter tre år. Hur lång tid en person behöver för att bearbeta sina erfarenheter i detta steg beror på hur mycket man påverkats av uppbindning och avskärmning, hur länge man har planerat avhoppet, hur länge man har levt som en passiv medlem, personens sociala situation (familj, vänner, yrke, 
arbete, intressen) och dennes personliga karaktäristik och hälsa.

\section{Relativ neutralitet}

Med «relativ neutralitet« menar jag att personen kommit över sina starkaste känslor gentemot organisationen och förhåller sig på ett relativt neutralt sätt gentemot organisationen. Helt neutral är, menar jag, inte möjligt att vara eftersom Jehovas vittnen i det svenska samhället hos de allra flesta, även de utan erfarenhet av organisationen, skapar associationer i olika riktningar. Av de avhoppare som jag intervjuat befinner sig de flesta i denna fas. Av dem som blev uteslutna inom ett år (före intervjutillfället) ger Frank intrycket av att han är relativt neutral i förhållande till Jehovas vittnens värdesystem. Men då har han också levt utan att gå på möten och "i tjänsten" i tre år innan han de facto blev utesluten. Dessutom medverkade han i ett TV-program som han anser fungerade som en hämnd för de kränkningar som han tyckte sig varit utsatt för i organisationen.

Felix, som var mer integrerad i församlingen innan han begärde att få bli utskriven ger intryck av att vägen mot relativ neutralitet är svårare än för Frank. Ingen i hans familj eller släkt, som alla är Jehovas vittnen, pratar med honom. Han var inte inbjuden till sin systers bröllop och han blev två dagar efter uteslutningen uppsagd från sin anställning på ett mindre företag där alla var Jehovas vittnen. Han studerar vid tiden för intervjun på den kommunala vuxenutbildningen (KomVux) för gymnasiekompetens. Han menar i intervjun att Jehovas vittnens prägling av honom har gjort det svårt i skolsituationen. Under hela hans tid $\mathrm{i}$ grundskolan var han mobbad, till en början genom att ständigt vara utanför och senare genom fysisk misshandel. Föräldrarna var medvetna om sonens skolsituation, men ansträngde sig inte för att försöka förändra sonens belägenhet. - Gud hade berättat genom Bibeln att de rättroende skulle bli förföljda. Så vad kunde de göra?

På grund av tidigare erfarenheter var det i början, när han återupptog studierna som vuxen, svårt att umgås på ett normalt sätt med de nya studiekamraterna. Felix säger att han blivit så van vid att vara utanför och dra sig undan i skolsituationen, att det har varit svårt att lämna sitt utanförskap. Han har också haft svårt för att vara kritiskt reflekterande som lärarna efterfrågar, eftersom han varit van vid Jehovas vittnens auktoritetstänkande. Felix ägnar en hel del tid åt ett avhopparnätverk och håller föreläsningar i skolor om sekters negativa påverkan. Håkan anser att arbetet i avhoppargrupperna måste upphöra för att avhopparen ska fortsätta att utvecklas. Felix är ännu inte mogen för denna utveckling utan tänker ofta på Jehovas vittnen och den påverkan organisationen haft på hans liv. Han är, genom det intresse han fortfarande ägnar organisationen, genom tankar och känslor, ännu inte ute ur floating-fasen.

Under utgångsprocessen kommer de uppbindande och avskärmande faktorerna som varit betydelsefulla under ingångsprocessen och medlemskapet att bli mindre och mindre betydelsefulla för medlemmarna. 


\section{Diskussion}

I artikeln framkommer flera typer av berättelser hur det är möjligt att hantera tvivel inom Jehovas vittnen. Inledningsvis finns det tre olika sätt att hantera tvivlet. Det går att gå i stark mottattack, det vill säga att som Felicia direkt ifrågasätta organisationen, det lite vanligare sättet är att fundera och älta som Håkan gjorde under sina 19 år före utgången. Ett tredje sätt att hantera de initiala tvivlen är att förklara dem med sina egna tillkortakommanden, som Fred gjorde. I undersökningsgruppen har bara funnits en person som representerar den hållningen och som fenomen bör Freds berättelse avkrävas en särskild analys. I samtalen med de avhoppade vittnena menar många att de tror att det finns en stor grupp av medlemmar som hoppat av för att de inte anser sig kunna uppfylla organisationens förväntningar på dem. Om man betänker den skam som en person upplever som inte klarar att uppfylla de krav som denne tror är centrala för detta liv och nästa går det att dra slutsatsen att dessa personer inte är positiva till att bli intervjuade. Misstanken hos många före detta att många är kvar av familjeskäl, att de stannar kvar tills hela familjen är beredd att gå ur är svåra att bekräfta utifrån studiens empiri (bekräftas dock i Beckford 1975). Att ingen av dem som intervjuats har lämnat kvar sin familj är en indikation att det kan vara så, även Håkans 19 års vånda innan utgången (då hela hans familj följde honom) pekar mot att det kan ligga en hel del sanning i misstanken. Flera berättar också om före detta vittnen som tagit sitt liv. Susan Alter (1992) refererar i en kanadensisk artikel till höga självmordstal bland uteslutna Jehovas vittnen och på chatsidan www.jehovahs-witness. net diskuterar medlemmar och före detta medlemmar om självmord hos aktiva och uteslutna medlemmar. Huruvida antalet självmord är högre hos Jehovas vittnen än i befolkningen i övrigt finns inga säkra uppgifter om. Vad som går att konstatera utifrån debatten hos initierade aktiva och före detta Jehovas vittnen är att självmord finns och att det är ett problem. Självmord betraktas inom organisationen som en synd och begravningar måste ske utanför församlingslokalerna.

Till skillnad från den tidigare forskningen kring utgångar har jag gjort utgångsmodellen som presenteras i artikeln mer flexibel. Det beror till stor del på det dagboksmaterial som jag fick ta del av. Under utgångsprocessen kan man känna "tvivel i varierande styrkau. Dessa tvivel prövas sedan på olika sätt, genom att läsa kritisk litteratur, genom samtal med andra och genom bibelstudier på egen hand eller i grupp. Dessa prövningar leder så småningom till vändpunkter eller insikter. Men till skillnad från Skonovd (1981) och Fuchs Ebaugh (1988a) menar jag att personen under utgångsprocessen genomgår flera vändpunkter/insikter.

Även om man kommer till slutsatsen att man vill gå ur organisationen, alltså en slags vändpunkt, kan det finnas skäl att inte verkställa beslutet just då. Man bedömer kanske att det inte är rätt tidpunkt att vända organisationen ryggen. Det finns naturligtvis även ett starkt motstånd hos individen att överge sin livssyn. Även besluten och stegen i verkställighe- 
ten tas vid flera tillfällen. Under slutfasen av medlemskapet och/eller under en tid efter ett avslutat medlemskap befinner sig den avhoppade personen i en period som jag benämner floating. Begreppet har jag lånat och utvecklat från tidigare forskning. Under denna fas bearbetar individen sin upplevelse av livet i organisationen. Bearbetningen innebär ofta att vederbörande går igenom känslor av sorg, ilska, kränkning och osäkerhet. Man reflekterar över sig själv i relation till organisationen och över det värdesystem som organisationen står för. Genom bearbetning kommer så småningom personen fram till en relativ neutralitet när hon eller han inte längre är dominerad av känslor och tankar om Jehovas vittnen. Att komma till denna punkt tar olika lång tid för berörda individer. Jag har gett exempel på att före detta medlemmar som har varit medlemmar i »avhopparorganisationer" då de befunnit sig i floatingfasen. När de alltmer frigjort sig från Jehovas vittnen har de även fjärmat sig från avhoppargrupperna.

För att komma fram till en "relativ neutralitet» har mina intervjupersoner genomgått en alternativ uppbindning som innebär att de riktar sig mot andra aktiviteter för att på det sättet få emotionell energi från något annat håll. Håkan och Fanny sjöng i kör och Frida började läsa den sortens böcker som organisationen avrådde medlemmarna från att läsa. För intervjupersonerna har det också varit nödvändigt att luckra upp den avskärmning som är resultatet av inkluderingsteknikerna. Ett första steg i denna frigörelse är insikten om att det faktiskt finns ett normsystem.

Modellens fördelar är dess flexibilitet, det vill säga att den ger utrymme för att beakta den tvekan, tvivel och villrådighet som jag stött på hos intervjupersonerna. Den är också baserad på ett unikt material och bidrar därmed till ny kunskap. Samtidigt kan naturligtvis modellen kritiseras för att den bara tillämpas på ett begränsat empiriskt material.

De angivna uppbindande och avskärmande faktorerna kan som tidigare nämnts vara svårare att lösgöra sig från ju längre tid i organisationen man har. Närhet och vänskap skapar trygghet samtidigt som det finns en baksida där ett avhopp upplevs som svek mot vännerna i församlingen. Den bekräftelse man som medlem kan erhålla i organisationen som äldstebroder, effektiv pionjär eller rekryterare av nya medlemmar kommer vid ett avhopp också betraktas som svek av de kvarvarande medlemmarna. De upplever sig lurade av personen som kanske predikat för dem på ett entusiasmerande sätt. Att personen sedan vänder tron och orden ryggen upplevs av församlingsmedlemmarna som grovt svek. Vad det gäller arbetssituationen ligger besvikelsen och förlusten oftare hos individen när denne förlorar sitt jobb och kontakter inom branschen. Även 'stängda dörrar' är en faktor vars effekter vid ett avhopp ligger till last på den enskilda individen. Vid ett längre medlemskap har personen oftast ingen utbildning, ingen position i samhället, oftast få eller inga fritidsintressen utanför församlingslivet, inget nätverk av vänner utanför församlingen eller någon roll i civilsamhället. 


\section{Slutord}

Vad kan vi då lära av detta? Att det är smärtsamt att tvivla på sin tro inom Jehovas vittnen. Att det finns lite kunskap om människor som vill lämna Jehovas vittnen och andra grupper är redan konstaterat. Vad som kanske bör uppmärksammas så här avslutningsvis är att individer som lämnar Jehovas vittnen inte går en rak väg ut ur organisationen. Beslutet måste ta sin tid, kan inte forceras och tvivlen måste hinna bearbetas. Man skulle kunna tänka sig att denna tvivlets och utgångens krokiga väg är något tvivlare inom Jehovas vittnen har gemensamt med andra typer av avhoppare.

\section{Referenser}

Albrecht Stan L., Cornwall Marie \& Cunningham Perry H. (1988) „Religious Leave Taking Disengagement and Disaffiliation Among Mormons". In David G. Bromley (ed.) Falling from the Faith, Causes and Consequences of Religious Apostasy. Newbury Park: Sage Publications.

Alter, Susan (1992) Jehovah's Witnesses: Disfellowshipping and shunning. Library of Parliament, Researach Branch. Law and Government Division. Canada.

Beckford, James A. (1975) The Trumpet of Prophecy - A Sociological Study of Jehovah's witnesses. Oxford: Basil Blackwell.

Beckford, James A. (1985) Cult Controversies. London: Tavistock Publication Ltd.

Bromley, David, G. (1997) „Falling from the New Faith - Toward an Integrated model of religious affiliation/disaffiliation". In W. Shaffir \& M. Bar-Lev (eds.) Religion and the Social Order, vol. 7, Leaving Religion and religious life. Greenwich, Connecticut: Jai Press.

Davidman, Lynn \& Greil, Arthur L. (2007) „Characters in Search of a Script: The Exit Narratives of Formerly Ultra-Orthodox Jewsu. Journal for the Scientific Study of Religion 46, (2), pp. 20-216.

Enander, Viveka (2008) Women Leaving Violent Men. Crossroads of Emotion, Gognition and Action. Avhandling i socialt arbete. Göteborg:
Göteborgs universitet, Institutionen för socialt arbete.

Fuchs Ebaugh, Helen Rose (1988a) Becoming an Ex - The process of Role Exit. Chicago: University of Chicago Press.

Fuchs Ebaugh, Helen Rose (1988b) „Leaving Catholic Convents: Toward a Theory of Disengagementu. In David G. Bromley (ed.) Falling from the Faith, Causes and Consequences of Religious Apostasy. Newbury Park: Sage Publications.

Gabriel, Y. (1991) "On organizational stories and myths: Why is it easier so slay a dragon than to kill a myth". International Sociology (6), pp. 427-442.

Galanter, Marc (1983) "Unification Church ('Moonie') Dropouts: Psychological Readjustment After Leaving a Charismatic Religious Group". American Journal of Psychiatry 140, (8), pp. 984-989.

Hedin, Ulla-Carin \& Månsson, Sven-Axel (1998) Vägen ut! Om kvinnors uppbrott ur prostitutionen. Stockholm: Carlsson Bokförlag.

Hydén, Lars-Christer (1997) "The institutional narrative as drama». I B-L. Gunnarsson, P. Lindell \& B. Norberg (eds.) The Construction of professional discourse. London: Longman.

Jehovah's Witnesses (1982) "A Wise Guide to Education". Watchtower, July 15, p. 11.

Jehovah's Witnesses (1998) „What Future do You 
Want for Your Children? "Watchtower, July 15, pp. 4-6.

Jehovah's Witnesses (1999) »Joyful Praisers». District Convention. Our Kingdom Ministry, 5.

Jehovah's Witnesses (2009) Annual Worldwide

Statistics. Hämtad februari 12, 2009, från http://www.jw-media.org/people/statistics. htm

Lewis, James R. \& Bromley, David G. (1987) »The Cult Withdrawal Syndrome: A case of Misattribution of Cause?". Journal for the Scientific Study of Religion 26, (4), pp. 508-522.

Liedgren Dobronravoff, Pernilla (2007) Att bli, att vara och att ha varit - om ingangar $i$ och utgaingar ur Jehovas vittnen i Sverige. Avhandling i socialt arbete. Lund: Lunds universitet, Socialhögskolan.

Lofland, John \& Skonovd, Norman (1981) „'Conversion Motifs'". Journal for the Scientific Study of Religion 20, (4), pp. 373-385.

Mauss, Armand L. (1973) "Dimensions of Religious Defection". In C. Y. Glock (ed.) Religion in Sociological Perspective: Essays in the Empirical Study of Religion. Californien: Wadsworth, Belmont.

Skonovd, Norman L. (1981) Apostasy: The Process of Defection From Religious Totalism. Ann Arbor: University Microfilms International.

Skonovd, Norman (1983) „Leaving the Cultic Religious Milieu». In David G. Bromley \& James T. Richardson (eds.) The Brainwashing/depro- gramming controversy, Studies in Religion and Society, vol. 5. New York: Edwin Mellen Press.

Socialstyrelsen (2003) Utmattningssyndrom Stressrelaterad psykisk ohälsa. Stockholm: Bjurner och Bruno AB.

Wright, Stuart A. (1983) "Defection from New Religious Movements: A test of some Theoretical Propositionsu. In David G. Bromley \& James T. Richardson (eds.) The Brainwashing/ Deprogramming Controversy. New York: Edwin Mellen Press.

Wright, Stuart A. (1984) „Post-Involvement Attitudes of Voluntary Defectors from Controversial New Religious Movements". Journal for the Scientific Study of Religion 23, (2), pp. 172-182.

Wright, Stuart A. (1986) "Dyadic Intimacy and Social Control in Three Cult Movements". Social Analysis 47, (2), pp. 137-150.

Wright, Stuart A. (1987) Leaving Cults: The Dynamics of Defection. Washington D.C.: Society for the Scientific Study of Religion.

Wright, Stuart A. (1988) „Leaving New Religious Movements; Issues, Theory and Research". In David G. Bromley (ed.) Falling from the Faith, Causes and Consequences of Religious Apostasy. Newbury Park: Sage Publications.

Wright, Stuart A. \& Piper, Elizabeth S. (1986) „Families and Cults: Familial Factors Related to Youth Leaving or Remaining in Deviant Religious Groups". Journal of Marriage and the Family 48,(1), pp. 15-25. 


\section{Summary}

\section{Leaving a world-about exit processes from Jehovah's Witnesses}

It is an everyday experience to realize that things do not turn out the as expected. But what if you realize that everything you have so far experienced as reality is illusion? This article is about former members of the Jehovah's Witnesses who have had doubts about what they previously believed to be the Truth. The article also treats the exit process, from being a Jehovah's Witness to becoming an ex-Jehovah's Witness. The data consists of twenty qualitative interviews with ten Jehovah's Witnesses and twenty qualitative interviews with ten former Jehovah's Witnesses. The data also include a diary written during four years preceding an exit from the organization. The analysis was made through thematic concentration. Ontologically the analysis and the article are based on a constructionist view though it is mainly empirical with no further theoretical assessment. However, to be able to understand the results a contextual frame is sketched with two fac- tors affecting members who make an exit. First there are tying factors that bind the person closer to the organization; these are closeness and friendship and confirmation. A secluding factor is something that secludes the member from the outside society; these factors are the work situation and "closed doors". With high values on these factors the exit process will be more arduous. The results are presented through a process model in which different phases or steps in the exit process are described. The following steps in the process are: (1) different levels of doubts; (2) trying out doubts; (3) turning points; (4) different decisions; (5) different steps in execution; (6) floating; (7) relative neutrality. The process is defined as an altogether ambivalent and emotionally tough experience, but other parts of life may be affected as well, such as employment, social life, family life and career. 